\title{
Tannin Supplementation in Animal Feeding; Mitigation Strategies to Overcome the Toxic Effects of Tannins on Animal Health: A Review
}

\author{
Aamir Nawab ${ }^{1, \dagger}$, Shuyan Tang ${ }^{1, \dagger}$, Wen Gao ${ }^{1}$, Guanghui $\mathrm{Li}^{1}$, Mei Xiao ${ }^{1}$, Lilong $\mathrm{An}^{1}$, Jiang Wu ${ }^{1}$ \& Wenchao Liu ${ }^{1}$ \\ ${ }^{1}$ Department of Animal Science, Agricultural College, Guangdong Ocean University, Zhanjiang 524088, \\ Guangdong, China \\ Correspondence: Lilong An, Department of Livestock Production and Management, Agricultural College, \\ Guangdong Ocean University, Haida Road, Mazhang District, Zhanjiang 524088, Guangdong, China. E-mail: \\ anlilong@126.com
}

Received: August 14, 2019

doi:10.5539/jas.v12n4p217

Accepted: November 10, 2019

Online Published: March 15, 2020

URL: https://doi.org/10.5539/jas.v12n4p217

${ }^{\dagger}$ These authors are equally contributed to this paper.

\begin{abstract}
Optimum animal production depends on the type of feedstuffs available for the whole year. Plants such as trees and shrubs have significance in the animal production due to high nutritious values of tannins which reduce the rumen protein degradability and improve the feed digestibility as well as amino acid absorption in the small intestine. But, some of these plant materials are usually rich in anti-nutritional factors, known as tannins. Tannins are a complex group of plant secondary compounds widely distributed in the plant kingdom. Tannins have both deleterious and advantageous effects depending on the types, doses, composition and concentration of tannins. Rural farmers face fodder scarcity during the winter season. Therefore, tannins containing browse species may help farmers to use tannins as supplementary feed for livestock. But higher concentrations of tannins cause metabolic disorder which in results reduces the animal productivity. Therefore, it is need to investigate the effects of tannin supplementation in animal feeding; mitigation strategies to overcome the toxic effects of tannins on animal health. In this review paper, we have discussed safety and hazard associated with tannins in animal feeding.
\end{abstract}

Keywords: animal performance, condensed tannins, digestibility, hydrolysable tannins, protein degradation

\section{Introduction}

Tannins are group of plant polyphenols present in all vascular plants including leguminous plants, forages, flowers, fruits, grasses and leguminous trees (Blackmon et al., 2016). First time, the word tannins was used by Seguim to explain the compound present in various plants extracts that have feature of converting animal hides to leather (Elgailani \& Ishak, 2016). Tannins are generally classified into two groups: hydrolysable tannins (HT) and condensed tannins (CT) (Table 1). Tannins have both harmful and beneficial effects depending on their nature, concentration, animal species, animal health and feed composition (Figures 1a and 1b). Several studies have reported that tannin based forages have anti-bloat and anthelmintic characteristics which improve the quality of meat and milk products, fatty acids composition and ruminant antioxidant status (Blackmon et al., 2016). In addition, these tannins containing plants also contribute to inhibit the enteric methane emission (Anantasook et al., 2016; Gunun et al., 2017). 
Table 1. Chemical nature of tannic acid

\begin{tabular}{ll}
\hline Name & Tannins \\
\hline Types & Condensed tannins and hydrolysable tannins \\
CAS number & $1401-55-4$ \\
Molecular formula & $\mathrm{C}_{76} \mathrm{H}_{52} \mathrm{O}_{46}$ \\
Molecular weight & $1701.206 \mathrm{~g} / \mathrm{mol}$ \\
Solubility in water & $2850 \mathrm{~g} / \mathrm{L}$ \\
Color & Light yellow to tan solid \\
Melting point & Decomposes above $200{ }^{\circ} \mathrm{C}$ \\
Flash point & $390{ }^{\circ} \mathrm{F}$ \\
Acidity(PKa) & Ca. 10 \\
\hline
\end{tabular}<smiles>O=C(O)c1cc(O)c(O)c(O)c1</smiles>

Gallic acid<smiles>Oc1cccc(O)c1O</smiles>

Pyragallol<smiles></smiles>

Ellagic acid

Figure 1a. Chemical structure of Hydrolysable tannins (HT) (Huang et al., 2018)<smiles>Oc1cc(O)c2c(c1)OC(c1ccc(O)c(O)c1)C(O)CC2c1ccc(O)c(O)c1</smiles>

Figure 1b. Chemical structure of condensed tannins (CT) (Huang et al., 2018)

Tannins have the ability to form complexes with protein, amino acids and polysaccharides. CT binds with protein and makes tannin-protein complexes unavailable for degradation by ruminal bacteria and these complexes $60 \%$ increase the absorption of amino acid in the small intestine (Jonker \& Yu, 2017). Some tannin containing plants induce the toxicity in ruminants and monogastric animals which in turn, decrease the feed intake, nutrient digestibility, protein availability and production performances (Bernes et al., 2000; Huang et al., 2018). Therefore, it is need to explore the different strategies to control the injurious effect of dietary tannins on animal health. The purpose of this review was to evaluate the effects of tannin supplementation in animal feeding; mitigation strategies to overcome the toxic effects of tannins on animal health and the limitation of tannins supplementation in animal nutrition and its possible consequences on ${ }^{\text {animals }}$.

\section{Effect of Tannins on Animals}

The forage quality has positive effects on animal health which can be reflected as enhanced feed palatability, growth rate and fiber digestion, protein metabolism as well as increased flow rate of essential amino acid (EAA), nitrogen utilization and carbohydrate metabolism (Gxasheka et al., 2015) (Figure 2). Tannins have ability to protect protein from rumen microbial enzyme by forming protein complexes or reducing the activities of microbial proteases. Tannin-protein complexes can reduce the degradation of proteins in the rumen and increase the absorption of essential amino acid (EAA) in the small intestine (Gxasheka et al., 2015). On the other hand, all tannin/protein complexes that resistant to the rumen environment may or may not be digested in the lower gastrointestinal tract (Priolo \& Vasta, 2007; Huang et al., 2018). Therefore, these tannin-protein complexes remain stable at acid $\mathrm{pH}$ of the abomasum and the proteins become available for absorption in the small intestine in dairy cattle (Alipour \& Rouzbehan, 2010; Mokni et al., 2017). 


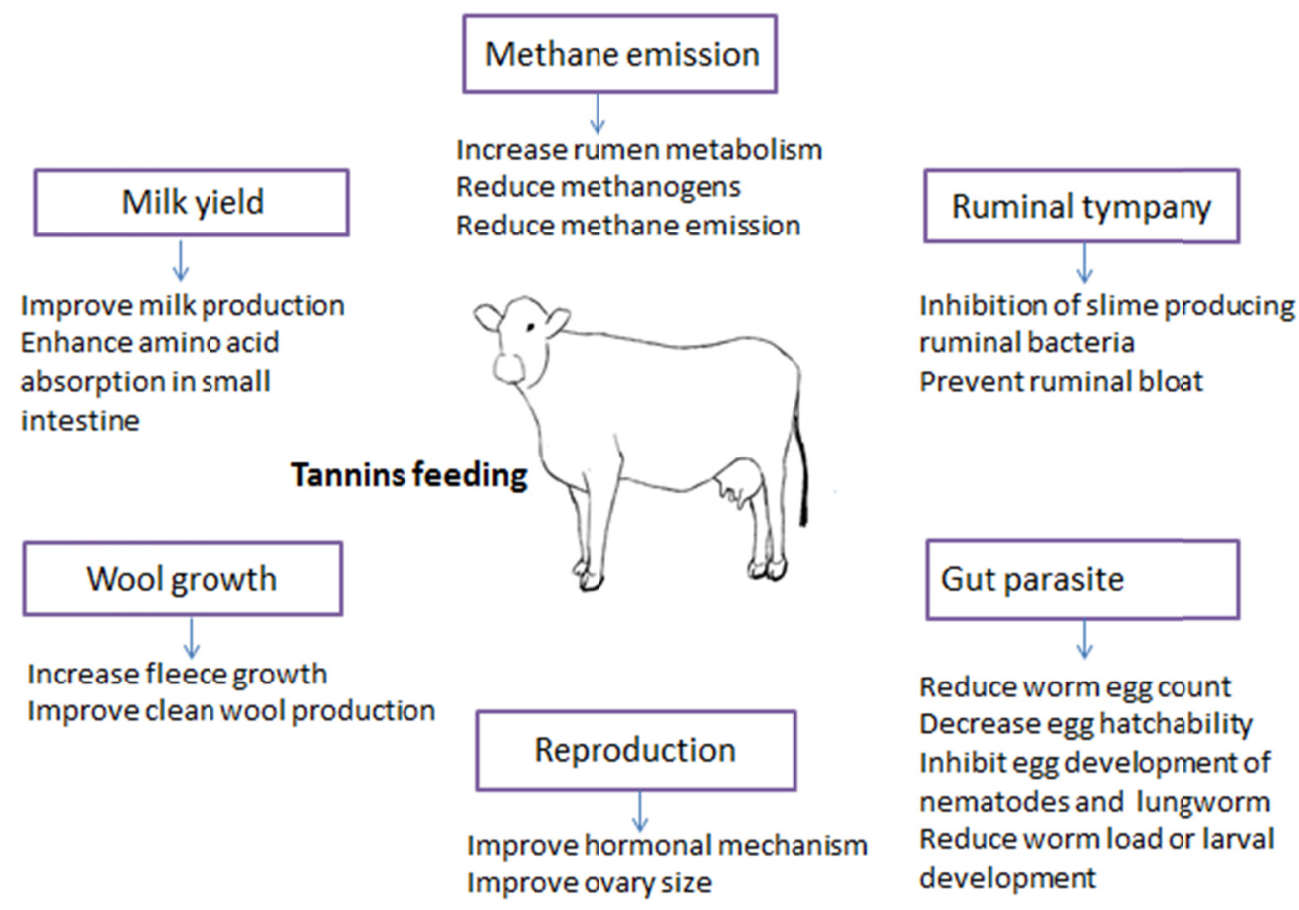

Figure 2. Advantageous effect of tannins feeding on animal health (Attia et al., 2016)

Phenols have different effect on intake and $\mathrm{N}$ retention, depending on the type of basal diet and dietary CP concentration. Forage given to ruminants observed that rumen ammonia concentrations were linked with the N concentration of forages (Naumann et al., 2013). Tannin rich forages have lesser ammonia concentrations than forages without tannins contents. The efficiency of urea recycling in the rumen may increase by dietary tannins supplementation (Blackmon et al., 2016). Tannins reduce the rate of protein degradation and deamination in the rumen and therefore ammonia concentration can be reduced in the rumen (Tiemann et al., 2008; Sahoo et al., 2010). A study has indicated that sheep and goats given tannins containing legumes had decreased rumen plasma urea $\mathrm{N}$ (nitrogen), ammonia $\mathrm{N}$, and urinary $\mathrm{N}$. Tannins may enhance the glycoprotein contents and saliva excretion which can lead to increase $\mathrm{N}$ recycling to the rumen (Naumann et al., 2013). Tannins plants increase microbial protein per unit of organic matter digested. In ruminants, the quantity of rumen protein bypass for absorption in the small intestine may not be sufficient to meet the metabolisable protein level (Belachew et al., 2013). Higher level of CT based feed cause the complete absence of soluble protein in the rumen, which in turn, decrease microbial and metabolisable protein synthesis providing less supply to the animals (Krueger et al., 2010). Hence, CT low concentration may be helpful to decrease the rumen degradability of feed protein and enhance the supply of microbial protein in lactating animals (Min et al., 2006). Generally, condensed tannins (CT) and hydrolysable tannin (HT) supplementation have no deleterious effects (dose dependent) on animal performance (Krueger et al., 2010). Several studies investigated that some tannins based forage are beneficial and some are deleterious (Dey \& De, 2014). Tannins higher concentrations reduce feed intake, carbohydrates metabolism, protein digestibility and ultimately animal production performance (Shewangzaw, 2016).

Tannins reduce feed intake and palatability due to astringency or by influencing the digestion. Palatability is dependent on CT concentration (Berchielli et al., 2006). Astringency is caused due to formation of tannins-salivary glycoproteins complexes (Frutos et al., 2004; Piluzza et al., 2013). This may decrease palatability and increase salivation (Min, Wilson, Solaiman, \& Miller, 2015). Many ruminant species have proteins rich proline in their saliva (Frutos et al., 2004). These have potential to bind with tannins (Shewangzaw, 2016). Tannin-proline rich protein complexes are stable throughout the whole intestinal tract. This might reduce the negative effect on feed palatability, feed intake, and increase the digestion of tannin-rich feeds. Authors reported that ruminants fed high tannins feed (leaves of Acacia seyal and A. cyanophylla and fruits of $A$. sieberiana) with Sesbania sesban (low tannins concentration) and three standard protein supplements (Vicia dasycarpa, andurea or noug) had reduced total feed intake (Eldin et al., 2014; Gxasheka et al., 2015; Jouany \& Morgavi, 2017). The rate of weight gain for young animals can be reflected by net feed intake and availability of nutrients in the diet. A study has observed that ruminants given high levels tannins fruits A. sieberiana 
(paperbark acacia) and $A$. nilotica (Vachellia nilotica) had less growth rates because of less feed intake (Ngwa et al., 2002). Less total feed intake and less growth rates were also observed in animals consuming tannins based $A$. sieberiana pods and leaves of $A$. cyanophylla (Acacia saligna). The adverse effect of tannins (dose dependent) on growth rate was reported due to decrease feed intake and protein digestibility (Blackmon et al., 2016).

Tannins reduce cell wall digestibility by binding bacterial enzymes or forming indigestible complexes with carbohydrates. Another study stated that sheep fed CT containing A. cyanophylla diet had reduced digestibility of organic matter and fiber fractions. Tannins higher levels (about 5-9\%) reduce the digestibility of the fiber in the rumen by inhibiting the activity of bacteria or anaerobic fungi (Frutos et al., 2004). High levels of tannins more than $5 \%$ badly also reduce the feed intake and above $9 \%$ tannins cause mortality in the animal (Frutos et al., 2004). The quantity of carbohydrate digestion depends on the type of the tannins feed degradability, fermentation and the amount of feed intake and excretion. If protein resists degradation or feed deficient in protein, (reduce microbial growth in the rumen) that can hinder carbohydrate metabolism (Shewangzaw, 2016). If ruminants consume high tannin diet, it can induce a deficiency of rumen-degradable $\mathrm{N}$ that indirectly reduces the function of structural carbohydrates (Shewangzaw, 2016). CT not only attaches to protein but also inhibit the carbohydrates metabolism in the rumen by making carbohydrates complexes resulting undegradation of carbohydrates (Frutos et al., 2004). Thus, there is need to focus tannin plants contents and tannins plant digestibility. A similar study also reported that it is important to differentiate between high phenolic plants (toxic), tannins containing nutritious plant (safe to use) and tannins based plants comprising more fibrous diet (Chafton, 2006).

\section{Role of Tannins on Animal Production}

Tannins have different effects on lactating animals. A study in dairy cattle has investigated that L. corniculatus increased $60 \%$ milk production and $10 \%$ milk protein quantity than control group (without CT). Min et al. (2003) reported that, ewes feeding CT based L. corniculatus had no effect on milk let-down in the early lactation, but secretion rates of whole milk, protein and lactose were increased by 21,14 and $12 \%$, respectively during mid and late lactation (Min et al., 2003). In dairy cows, CT increased milk quantity but no effects were observed on feed intake. However, various studies described that black wattle tree (Acacia mearnsii) bark containing CT concentration had no effects on dairy cows milk production (Gerlach et al., 2018). Dairy ewes fed quebracho tannins (QT) and acacia species had decreased milk yield. Several other studies suggest that mechanism behind increase milk production was due to protein protection from rumen microbial degradation which results in enhanced milk production in dairy cows, goats and sheep (Attia et al., 2016). These consequences were expected due to chemical composition, properties and chemical reactivity of tannins which in turn deviates the rumen microbial ecosystem and volatile fatty acids concentration (Valentina Vasta et al., 2010; Minieri et al., 2014; Carreno et al., 2015).

Protein plays a key role in the clean wool production consisting high cysteine quantity in the feed but amino acids containing sulphur has harmful effect on wool production. CT forages increase loss rate of cystine from blood plasma, mainly due to reducing the loss of sulphur containing amino acids (SAA) in the rumen. Addition of CT in diet increase fleece growth due to increasing the absorption of SAA (Chanjula et al., 2004; Waghorn, 2008; Pathak et al., 2017). Wool growth depends upon both the type and concentration of CT. Some studies revealed that CT containing Hedysarum coronarium (sulla) and L. pedunculatus above $50 \mathrm{~g} / \mathrm{kg} \mathrm{DM}$ impair wool growth. However, the response of wool growth was variable when CT quantity reduced below $22 \mathrm{~g}$ CT/kg DM. According to Priolo et al. (2000), CT extracted from L. corniculatus $35 \mathrm{~g} / \mathrm{kg}$ DM increased the wool growth in lambs. Therefore, CT based L. corniculatus 22-38 g/kg DM demonstrated better effects for wool production. The results variation was due to difference in chemical composition and concentration of CT, which can affect its biological activity (Pathak et al., 2017). Tannins plants are good source of amino acids which plays an important role in the process of ovulation (Attia et al., 2016). The nutritional effect is possibly connected with hormonal pathway of ovary. It has reported that essential amino acid (EAA) and plasma branched chain amino acid (BCAA) are mutually related to increases the intravenous infusion of BCAA (Puchala et al., 2005; Ying et al., 2011). On other hand, in vitro study reported that the sensitivity of muscle protein to insulin have been enhanced by BCAA. Numerous studies determined that only enzyme BCAA transferase present in the ovaries. These consequences explain that cytosolic enzyme-BCAAT play a role for the progressive decrease of BCAA in skeletal muscles of sheep (Faure, Glomot, \& Papet, 2001). The above finding shows that BCAA have a direct positive effect on ovaries. But the phenomenon behind this enhancing effect is unknown.

One of the main health and welfare problems in ruminants is helminthiasis (worm infection). Gut parasitic infection causes mortality in sheep and goats etc. (Canul-Ku et al., 2012; Carvalho et al., 2012). The worm infection cause incidence of diarrhea and affect the calf health (Hounzangbe-Adote et al., 2005; Gxasheka et al., 
2015). Iqbal et al. (2007) has reported that tannins based forages have anthelmintic effects which reduce diarrhea and parasitic load (Figure 3). Various CT-rich plants have direct anthelmintic (antiparasitic) property to influence the life cycle of nematodes including worm egg count, worm fecundity and egg hatchability (Athanasiadou et al., 2001; Nguyen et al., 2005; Githiori et al., 2006; Alonso-Díaz et al., 2011; Mejia-Hernandez et al., 2014; Wang et al., 2015). A study in sheep has observed that CT containing sainfoin reduced egg hatchability of Trichostrongylus colubriformis and inhibited the egg development of nematodes and lungworm (Strongyloides spp., Ostertagia spp., Cooperia spp., Oesophagostomum spp. and Trichostrongylus spp.) depending on dose duration (Molan et al., 2002; Heckendorn et al., 2007; Wang et al., 2015; Bhattarai et al., 2016). In vivo research found that anthelmintic factor related with ingestion of tannins-rich plants may vary depending on the parasitic stages or the parasitic species (Martinez-Ortiz-de-Montellano et al., 2010). These examples of internal parasite inhibition create an important question for CT research because more consideration is given on defining the safe and threshold level of tannins in animals feed.

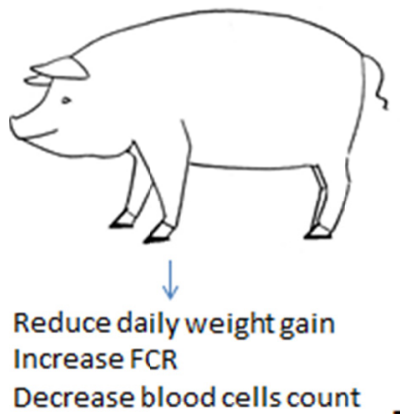

Toxic dose: 125, 250, 500 or $1,000 \mathrm{mg} \mathrm{TA} / \mathrm{kg}$

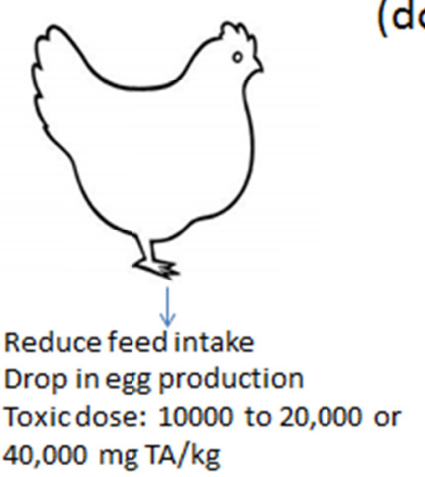

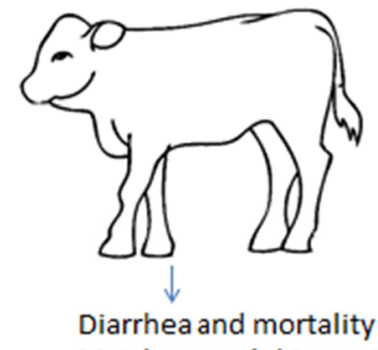

Met-haemoglobinaemia

Renal failure

Toxic dose: $>4400 \mathrm{mg} / \mathrm{kg} \mathrm{BW}$

\section{Toxic effects of tannin feeding (dose dependent)}

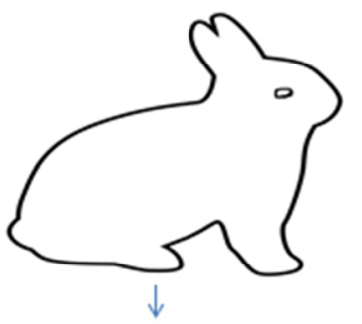

No injurious effects on growth rate and FCR

Toxic dose: $>10000 \mathrm{mg} \mathrm{TA} / \mathrm{kg}$

Figure 3. Toxic effect of tannins feeding on various animals (EFSA, 2014)

Bloat is a digestive disorder in ruminants that occurs due to consuming highly digestible leguminous plants. These plants produce the frothy gas and prevent the escape of rumen gases which causes obstruction and results in death of ruminants (Wang et al., 2012; Attia et al., 2016). Several authors have exposed that CT containing forages such as Lotus corniculatus, Coronilla varia, Onobrychis vicciifolia and Astragalus cicer L. fed sole diet or mixed with bloat forming fodder prevent bloat by making protein complexes in the rumen (Mueller-Harvey, 2006; Rochfort, 2008; Wang et al., 2012). Therefore, plants containing tannins have significant role in bloat reduction in the ruminants. However, the phenomenon is not clear that how tannins molecular reaction prevent bloat (Marles et al., 2003). But it is thought that CT can prevent bloat by inhibiting slime producing bacteria or disturbing the reaction of proteinaceous frothy foam (Ehsan et al., 2013; Shewangzaw, 2016).

\section{Effect of Tannins Toxicity on Different Animal Species}

Tannin containing feedstuffs have various dose dependent toxic effects on animal species (Figure 3). Oak toxicity is a major problem in cattle (Pérez et al., 2011). The harmful effect of HT has been observed when ruminants consume immature leaves of oak plants. Several studies have revealed that calves fed HT containing leaves of oak plants indicated clear toxicity (Pérez et al., 2011). A study has clearly determined that calves fed low concentration of tannins diet remained healthy, whereas the possible symptoms of renal failure appeared 
when calves supplemented with oak leaves (Guitart et al., 2010). Clinical sign such as methaemoglobinaemia, renal failure was appeared when calves consumed tannins diet at $>4400 \mathrm{mg} / \mathrm{kg} \mathrm{BW}$ (Guitart et al., 2010; Pérez et al., 2011).

Rumen microbial fermentation plays an important role in the prevention of tannins toxicity (EFSA, 2014). Therefore, mature animals can tolerate HT concentration in the range 15,000-25,000 $\mathrm{mg} / \mathrm{kg}$ diets without affecting performance, milk quantity or growth factor (Frutos et al., 2004; Krueger et al., 2010; Liu et al., 2013). Toxicity seems to be more prone to calves, but the high quantity of tannins diet at $>1500 \mathrm{mg} / \mathrm{kg}$ feed produce clinical symptoms as compared to recommended dose for flavoring practices (EFSA, 2014). More specifically, higher tannins concentration causes toxicity than low concentration. Mostly, tannins were derived from commercial products sweet chestnut (Castanea sativa). Tannin toxicity has been investigated for various species of ruminal bacteria for example Streptococcus bovis, Fibrobacter succinogenes, Ruminobacter amylophilis, Butyvibrio fibrosolvens, and Prevotella ruminicola. These tannins plants cause enzyme inactivation, substrate deficiency, damage membranes, ulcers in the rumen, necrosis of the mucosal folds and metal ion deficiency which in turn, affect the rumen digestibility (Pérez et al., 2011).

A study in pigs for fattening traits has found that growth performance was not affected by the addition of 2000 mg TA/kg from sweet chestnut (Prevolnik et al., 2012). A similar study has investigated that average daily gain in piglets were unaffected with the supplementation of $1500 \mathrm{mg}$ of a TA/kg feed, and no negative effects were observed on blood profile during 21 days trials (Bilić-Šobot et al., 2016). On the other hand, another similar study described that piglets fed $125,250,500$ or $1,000 \mathrm{mg} \mathrm{TA} / \mathrm{kg}$ diet had increased feed conversion ratio, reduced average daily gain, red blood cell count, and hematocrit respectively, under 28 days experiments (Lee et al., 2010). The blood profile seemed to be more prone at $1,000 \mathrm{mg}$ tannin $/ \mathrm{kg}$. However, the effects were not clear at lower concentration. For animal husbandry application, the disadvantageous effects appear at $250 \mathrm{mg}$ tannin/ $\mathrm{kg}$ diet (Bilić-Šobot et al., 2016). A study on male rabbits in New Zealand has revealed that there was no deleterious effect associated with tannin supplementation as compared to control groups (without tannic acid (TA) from chestnut wood) under 21 days experiments (Liu et al., 2011, 2012). A study has found that rats given different concentration of tannic acid at $5,10,15$ and $20 \mathrm{~g} / \mathrm{kg}$ feed respectively influences the iron absorption (Afsana et al., 2004; Karamac, 2009).

\section{Mitigation Strategies to Overcome Tannin Toxicity}

Various studies provide mitigation strategies to control the injurious effects of tannins feeding (Figure 4). There are a number of effective techniques to extract tannins from plants. Local feedstuffs containing tannins can be effectively used for livestock if a simple and economically viable detannification process is developed. Wood ash is a good source of alkali which has practiced at an industrial scale (Brown et al., 2016). Specifically, it has been described that soaking feed with alkaline or water solutions separate tannins toxic compounds from the most nutritive parts and thus enhance the palatability of feed (Kyarisiima \& Svihus, 2004). A study has investigated that magadi soda containing alkalies (sodium carbonate, sodium bicarbonate and sodium sesquicarbonate) has minimized 40 to 50\% tannins toxic effect in sorghum (Ben Salem et al., 2005). Wood ash solutions have also been utilized for treatment of tannins containing millet and sorghum for human intake. Therefore, application of wood ash has potential for detannification of tannins compounds. 


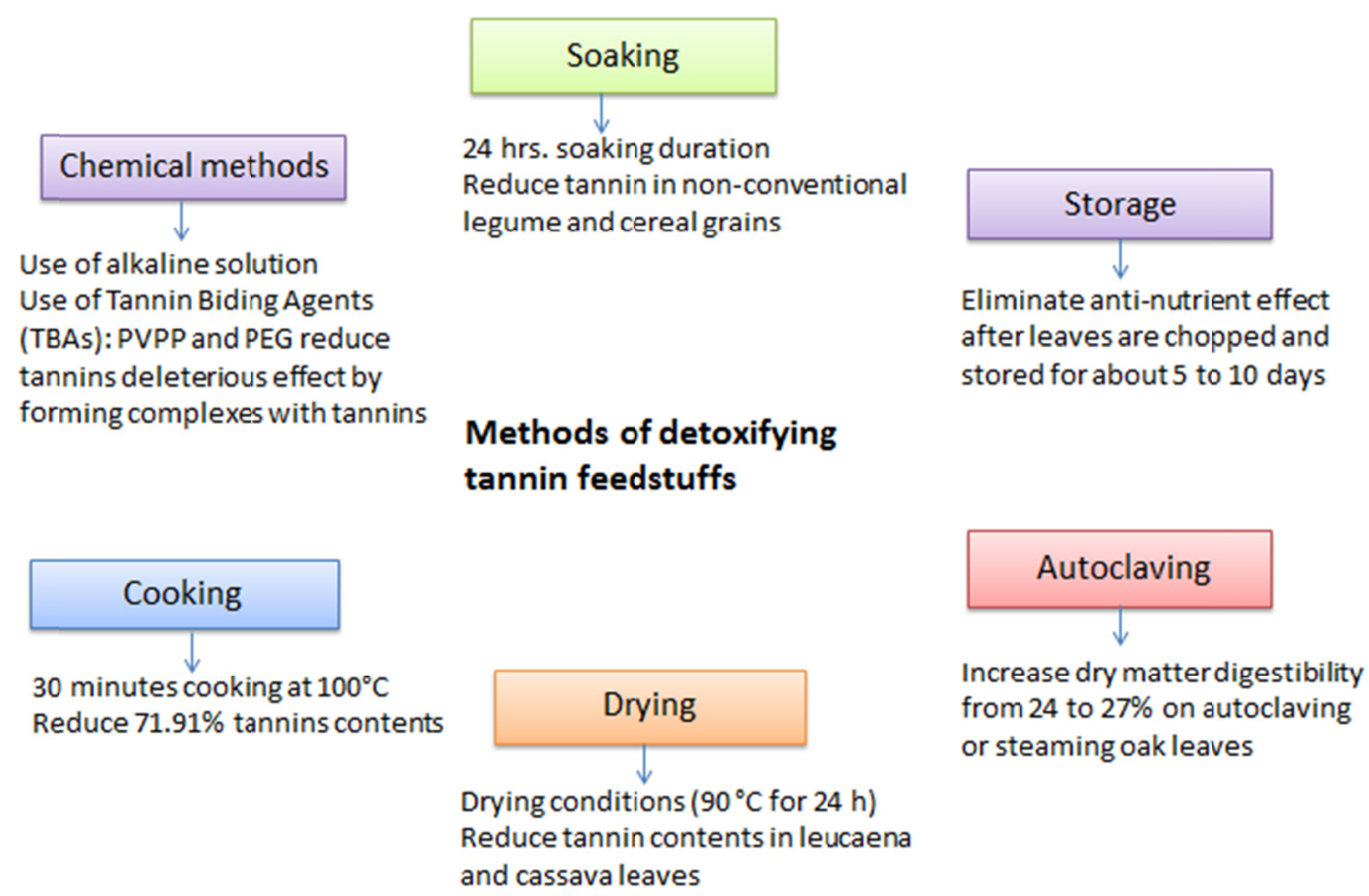

Figure 4. Mitigation strategies to reduce toxic effect of tannins feeding (Brown et al., 2016)

The forages chopping and preservation is a common practice at animal farming that is being used without any problem. It needs only to change farm routine practices. The leaves are chopped and stored for about 5 to 10 days before feeding. Several authors have proposed that the higher extent of tannin inactivation might be due to tannins oxidation by phenol oxidases present in the leaves, as chopping increase the availability of tannins to the enzyme. Moreover, tannin inactivation during storage and preservation was due to their polymerisation to higher inert polymers. The above mentioned technologies for detannification (tannin inactivation) of plants can be used by farmers' at small level. Drying of oak leaves under various conditions $\left(90^{\circ} \mathrm{C}\right.$ for $24 \mathrm{~h}, 60{ }^{\circ} \mathrm{C}$ for $48 \mathrm{~h}$, sun drying for 24 and $48 \mathrm{~h}$ and shade drying for 24, 48 and $72 \mathrm{~h}$ ) had no negative effect on the levels of CT, total phenols, degree of polymerization, protein precipitation capacity and specific activity of tannins (Brown et al., 2016). On the other side, drying conditions $\left(90{ }^{\circ} \mathrm{C}\right.$ for $\left.24 \mathrm{~h}\right)$ reduced tannin concentration in leucaena and cassava leaves. Various studies have different consequences due to different moisture level in these leaves. Oak leaves had about $40 \%$ whereas leucaena and Cassava leaves had $65 \%$ moisture. Increasing moisture of oak leaves under heat treatment decreased tannin levels. A similar study has found that water removal from leucaena leaves by lyophilisation (freeze-drying) also decreased the level of tannin inactivation under heat treatment (Brown et al., 2016). The autoclaving and/or steaming of oak leaves for 10 to $20 \mathrm{~min}$ had no effects on the level of condensed tannins, total phenols, ellagitannin and precipitation capacity of protein (Medugu et al., 2012). Autoclaving and steaming of ground leaves for 10 min decreased protein precipitation capacity by 53 and $25 \%$, respectively (Medugu et al., 2012). In sacco experiment has reported that dry matter digestibility was increased from 24 to $27 \%$ by autoclaving or steaming. The above drying procedure does not specific for detanninfication of oak leaves, but it can be used for fodder containing higher moisture level (Brown et al., 2016).

Tannins bind to polyvinyl-polypyrrolidone (PVPP), polyethylene glycol (PEG) and calcium hydroxide (Ben Salem et al., 2000; Makkar, 2003; Petek \& Dikmen, 2006). PVPP is water insoluble, synthetic polymer that plays an effective role in absorption and precipitation of tannins concentration. Therefore, PVPP is utilized where astringency needs to be reduced (Medugu et al., 2012). Several authors have used PEG treatment in different plants containing tannins to evaluate the effects of tannins on rumen metabolism (Frutos et al., 2004). A lot of studies have investigated that application of PEG had advantageous effects for local feedstuffs containing 5-10\% CT such as Acacia karroo, Quercus calliprinos, Pistacia lentiscus, Ceratonia siliqua, Zizyphus nummularia, Hedysarum coronarium, Acacia aneura, Lotus pendunculatus, Desmodium ovalifolium and Flamingia macrophylla (Brown et al., 2016). Detannification through PEG increases the nutrients availability and decrease microbial inhibition, which in turn, improve the animal production (Makkar, 2003). PEG treatment to $1 \%$ CT based L. corniculatus did not show any effect. This suggests that $1 \%$ CT from L. corniculatus was insufficient to 
protect the feed protein from rumen degradation. The effect of PEG depends on the proteins level in the forages. The forages containing higher proteins reduce the effect of PEG (Medugu et al., 2012). Therefore, the above findings suggest that addition of PEG in tannins containing diets may beneficial for ruminants (Petek \& Dikmen, 2006).

Various studies have found that extraction with aqueous organic solvents such as ethanol (40\%), acetone (30\%), and methanol (50\%) decreased 70\% tannins from oak leaves (Vitti et al., 2005). The benefit of organic solvents is that it can be reused and tannins can be utilized for tanning of leather. Plants treated with alkaline solution reduced 70 to $90 \%$ tannins concentration. The reduction in tannins was due to oxidation of tannins by oxygen at high $\mathrm{pH}$ level. Application of oxidizing agents and alkalis has the potential to inactivate tannins in oak leaves (Vitti et al., 2005). Both chemical and protein precipitation techniques showed that tannins storage at different temperature and $\mathrm{pH}$ values decreased tannin levels (Medugu et al., 2012). The stirring of plants containing tannins increased the rate of inactivation due to increase oxygen exposure. These findings suggested that the decrease in tannins was due to tannins inactivation. In addition, several industries can use hydrogen peroxide (oxidizing agent) to detanninified oak leaves as well as local feedstuffs for example Acacia karroo, A. nilotica, Mangifera indica and Tamarindus indica (Brown et al., 2016). It reduces 99\% tannin contents in these plants. These detannification techniques can be applied to remove tannin from the agro-industrial by-products which may help to control the problem forages toxicity in future (Medugu et al., 2012).

\section{Safety and Risk Associated With Tannin Feeding}

Tannic acid as a feed additive is safe (dose dependent) for all animals and no environmental hazardous effects have been documented. However, in vitro trials in rats found genotoxicity, but in vivo studies did not report genotoxicity and oral exposure related carcinogenicity (EFSA, 2014). Panel on Additives and Products used in Animal Feed (FEEDAP) also did not report tannins based reproductive toxicity. In addition, the above panel has declared that tannins caused hazardous effects to workers via inhalation or direct exposure with mucous membrane, eye and skin (EFSA, 2014). Therefore, it is recommended that caution should be taken before use of tannic acid in animal ration (Table 2).

Table 2. Recommended dose of tannic acid in animal feeding

\begin{tabular}{|c|c|c|c|c|}
\hline Species & Recommend dose & Negative effects & Overdose negative effects & References \\
\hline & \multicolumn{3}{|c|}{ 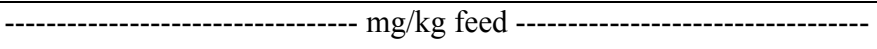 } & \\
\hline Adult ruminants & 15,000 & No & $>15,000$ & (EFSA, 2014) \\
\hline Laying hens & 10,000 & No & $>10,000$ & \\
\hline Rabbits & 10,000 & No & $>10,000$ & \\
\hline Pigs (fattening) & 1500 & No & $>1500$ & \\
\hline Chickens (fattening) & 1000 & No & $>1000$ & \\
\hline Weaned piglets & 125 & No & $>125$ & \\
\hline Young animal (calves) & $>1500$ & $>1500$ & $>1500$ & \\
\hline All animals & 15 & No & No & \\
\hline
\end{tabular}

\section{Conclusion and Future Recommendation}

Tannic based plants have both advantageous and injurious effects on animal health depending on the amount of feed intake, concentration, composition and time duration. These plants have potential to control gastrointestinal parasites and reduce the ruminal tympany. These plants (trees, shrubs and bushes etc.) can be used for livestock to fulfill the requirement of rural farmer during fodder scarcity in the winter season. But preventive measures should be taken before application of tannins in the animal ration. Tannin concentration more than 5\% badly affects voluntary feed intake and cause mortality. Thus, mitigation strategies may help to remove the toxic effects of tannins containing feedstuffs which might favorable for animal production. Therefore, optimum amount of tannin containing plants should be used in the animal feeding to enhance ruminant production. Very fewer studies have focused the effects of HT on animal health. Hence, further research is required to understand the potential role of HT in the animal feeding. It is necessary to explore the better utilization of tannin-containing plant species and evaluate HT associated toxicity in animals. Taken together, it has been suggested that the 15 $\mathrm{mg} \mathrm{TA} / \mathrm{kg}$ diet is safer for all animals. 


\section{Acknowledgements}

Special thanks to Journal of Agricultural Science for giving an opportunity to share knowledge on tannin supplementation in animal feeding. The author wishes to thank beloved parents (Rana Nawab Ahmad and Mrs. R. Sultana), grandparents (Saith Bachal Din), uncle (Rana Maqbool Ahmad), brother (Rana Kashif Nawab and Dr. Rana Yasir Nawab) and dearest all teachers for continued support and excellent mentorship. This work was supported by Science and Technology Planning Project of Guangdong Province, China (2010 B090400376).

\section{References}

Afsana, K., Shiga, K., Ishizuka, S., \& Hara, H. (2004). Reducing effect of ingesting tannic acid on the absorption of iron, but not of zinc, copper and manganese by rats. Bioscience, Biotechnology, and Biochemistry, 68(3), 584-92. https://doi.org/10.1271/bbb.68.584

Alipour, D., \& Rouzbehan, Y. (2010). Effects of several levels of extracted tannin from grape pomace on intestinal digestibility of soybean meal. Livestock Science, 128(1), 87-91. https://doi.org/10.1016/j.livsci. 2009.11.003

Alonso-Diaz, M. A., Torres-Acosta, J. F. J., Sandoval-Castro, C. A., \& Hoste, H. (2011). Comparing the sensitivity of two in vitro assays to evaluate the anthelmintic activity of tropical tannin rich plant extracts against Haemonchus contortus. Veterinary Parasitology, 181(2-4), 360-364. https://doi.org/10.1016/j.vetpar. 2011.03.052

Anantasook, N., Wanapat, M., Gunun, P., \& Cherdthong, A. (2016). Reducing methane production by supplementation of Terminalia chebula Retz. containing tannins and saponins. Animal Science Journal, 87(6), 783-790. https://doi.org/10.1111/asj.12494

Athanasiadou, S., Kyriazakis, I., Jackson, F., \& Coop, R. L. (2001). Direct anthelmintic effects of condensed tannins towards different gastrointestinal nematodes of sheep: in vitro and in vivo studies. Veterinary Parasitology, 99(3), 205-219. https://doi.org/10.1016/S0304-4017(01)00467-8

Attia, M. F. A., El-din, A. N. M. N., El-zarkouny, S. Z., \& El-zaiat, H. M. (2016). Impact of Quebracho Tannins Supplementation on Productive and Reproductive Efficiency of Dairy Cows. Journal of Animal Sciences, 6, 269-288. https://doi.org/10.4236/ojas.2016.64032

Belachew, Z., Yisehak, K., Taye, T., \& Janssens, G. P. J. (2013). Chemical composition and in sacco ruminal degradation of tropical trees rich in condensed tannins. Czech Journal of Animal Science, 58(4), $176-192$. https://doi.org/10.17221/6712-CJAS

Ben Salem, H., Nefzaoui, A., Ben Salem, L., \& Tisserand, J. L. (2000). Deactivation of condensed tannins in Acacia cyanophylla Lindl. foliage by polyethylene glycol in feed blocks: Effect on feed intake, diet digestibility, nitrogen balance, microbial synthesis and growth by sheep. Livestock Production Science, 64(1), 51-60. https://doi.org/10.1016/S0301-6226(00)00175-5

Ben Salem, H., Nefzaoui, A., Makkar, H. P. S., Hochlef, H., Ben Salem, I., \& Ben Salem, L. (2005). Effect of early experience and adaptation period on voluntary intake, digestion, and growth in Barbarine lambs given tannin-containing (Acacia cyanophylla Lindl. foliage) or tannin-free (oaten hay) diets. Animal Feed Science and Technology, 122(1-2), 59-77. https://doi.org/10.1016/j.anifeedsci.2005.04.014

Bernes, G., Waller, P. J., \& Christensson, D. (2000). The effect of birdsfoot trefoil (Lotus corniculatus) and white clover (Trifolium repens) in mixed pasture swards on incoming and established nematode infections in young lambs. Acta Veterinaria Scandinavica, 41(4), 351-361.

Bhattarai, S., Coulman, B., \& Biligetu, B. (2016). Sainfoin (Onobrychis viciifolia Scop.): Renewed interest as a forage legume for western Canada. Canadian Journal of Plant Science, 756(April), 748-756. https://doi.org/ 10.1139/cjps-2015-0378

Bilić-Šobot, D., Kubale, V., Škrlep, M., Čandek-Potokar, M., Prevolnik Povše, M., Fazarinc, G., \& Škorjanc, D. (2016). Effect of hydrolysable tannins on intestinal morphology, proliferation and apoptosis in entire male pigs. Archives of Animal Nutrition, 70(5), 378-388. https://doi.org/10.1080/1745039X.2016.1206735

Blackmon, T. K., Muir, J. P., Wittie, R. D., Kattes, D. H., Barry, D., Blackmon, T. K., ... Kattes, D. H. (2016). Effects of simulated and insect herbivory on nitrogen and protein precipitable phenolic concentrations of two legumes. Journal of Plant Interactions, 11(1), 61-66. https://doi.org/10.1080/17429145.2016.1172128

Brown, D., N, J. W., \& Norris, D. (2016). Feed potential of acacia karroo leaf meal for communal goat production in southern africa: A review. The Journal of Animal \& Plant Sciences, 26(4), 1178-1186. 
Canul-Ku, H. L., Rodríguez-Vivas, R. I., Torres-Acosta, J. F. J., Aguilar-Caballero, A. J., Pérez-Cogollo, L. C., \& Ojeda-Chi, M. M. (2012). Prevalence of cattle herds with ivermectin resistant nematodes in the hot sub-humid tropics of Mexico. Veterinary Parasitology, 183(3), 292-298. https://doi.org/10.1016/j.vetpar. 2011.07.029

Carreno, D., Hervas, G., Toral, P. G., Belenguer, A., \& Frutos, P. (2015). Ability of different types and doses of tannin extracts to modulate in vitro ruminal biohydrogenation in sheep. Animal Feed Science and Technology, 202, 42-51. https://doi.org/10.1016/j.anifeedsci.2015.02.003

Carvalho, C. O., Chagas, A. C. S., Cotinguiba, F., Furlan, M., Brito, L. G., Chaves, F. C. M., ... Amarante, A. F. T. (2012). The anthelmintic effect of plant extracts on Haemonchus contortus and Strongyloides venezuelensis. Veterinary Parasitology, 183(3-4), 260-268. https://doi.org/10.1016/j.vetpar.2011.07.051

Chafton, L. (2006). the Effect of a Condensed Tannin Containing Forage, Sericea Lespedeza, on Existing and Challenge Infections of Haemonchus contortus in Sheep. Annals of Physics, 54(2), 47.

Chanjula, P., Wanapat, M., Wachirapakorn, C., \& Rowlinson, P. (2004). Effects of various levels of cassava hay on rumen ecology and digestibility in swamp buffaloes. Asian-Australasian Journal of Animal Sciences, 17(5), 663-669. https://doi.org/10.5713/ajas.2004.663

Dey, A., \& De, P. S. (2014). Influence of Condensed Tannins from Ficus bengalensis Leaves on Feed Utilization, Milk Production and Antioxidant Status of Crossbred Cows. Asian Australas. J. Anim. Sci., 27(3), $342-348$. https://doi.org/10.5713/ajas.2013.13295

Downing, J. A., \& Scaramuzzi, R. J. (1991). Nutrient effects on ovulation rate, ovarian function and the secretion of gonadotrophic and metabolic hormones in sheep. Journal of Reproduction and Fertility, 43(January), 209-227.

Ebrahim, R., Liang, J. B., Jahromi, M. F., Shokryazdan, P., Ebrahimi, M., Li Chen, W., \& Goh, Y. M. (2015). Effects of Tannic Acid on Performance and Fatty Acid Composition of Breast Muscle in Broiler Chickens Under Heat Stress. Italian Journal of Animal Science, 14(4), 3956. https://doi.org/10.4081/ijas.2015.3956

EFSA. (2014). Scientific opinion on the safety and efficacy of tannic acid when used as feed flavouring for all animal species. EFSA, 12(10), 2-18. https://doi.org/10.2903/j.efsa.2011.2416

Ehsan O., Abdullah N., \& Oskoueian, A. (2013). Effects of Flavonoids on Rumen Fermentation Activity, Methane Production, and Microbial Population. BioMed Research International, 2013, 1-9. https://doi.org/ $10.1155 / 2013 / 349129$

Eldin, I., Elgailani, H., \& Ishak, C. Y. (2014). Determination of Tannins of Three Common Acacia Species of Sudan. Advances in Chemistry, 2014, 1-6. https://doi.org/10.1155/2014/192708

Elgailani, I. E. H., \& Ishak, C. Y. (2016). Methods for Extraction and Characterization of Tannins from Some Acacia Species of Sudan. Pakistan Journal of Analytical \& Environmental Chemistry, 17(1), 43-49. https://doi.org/10.21743/pjaec/2016.06.007

Faure, M., Glomot, F., \& Papet, I. (2001). Branched-Chain Amino Acid Aminotransferase Activity Decreases during Development in Skeletal Muscles of Sheep. The Journal of Nutrition, 131(5), 1528-1534. https://doi.org/10.1093/jn/131.5.1528

Frutos, P., Hervas, G., Giraldez, F. J., \& Mantecon, A. R. (2004). Review: Tannins and ruminant nutrition. Spanish Journal of Agricultural Research, 2(2), 191-202. https://doi.org/10.5424/sjar/2004022-73

Frutos, P., Raso, M., Hervás, G., Mantecón, A. R., Giráldez, F. J., \& Pérez, V. (2004). Is there any detrimental effect when a chestnut hydrolysable tannin extract is included in the diet of finishing lambs? Animal Research, 53(2), 127-136. https://doi.org/10.1051/animres:2004001

Gerlach, K., Pries, M., Tholen, E., Schmithausen, A. J., Büscher, W., \& Südekum, K.-H. (2018). Effect of condensed tannins in rations of lactating dairy cows on production variables and nitrogen use efficiency. Animal, 1-9. https://doi.org/10.1017/S1751731117003639

Githiori, J. B., Athanasiadou, S., \& Thamsborg, S. M. (2006). Use of plants in novel approaches for control of gastrointestinal helminths in livestock with emphasis on small ruminants. Veterinary Parasitology, 139(4), 308-320. https://doi.org/10.1016/j.vetpar.2006.04.021

Guimarães-Beelen, P. M., Berchielli, T. T., Beelen, R., Araújo Filho, J., \& Oliveira, S. G. De. (2006). Characterization of condensed tannins from native legumes of the Brazilian northeastern semi-arid. Scientia Agricola, 63(6), 522-528. https://doi.org/10.1590/S0103-90162006000600002 
Guitart, R., Croubels, S., Caloni, F., Sachana, M., Davanzo, F., Vandenbroucke, V., \& Berny, P. (2010). Animal poisoning in Europe. Part 1: Farm livestock and poultry. The Veterinary Journal, 183(3), $249-254$. https://doi.org/10.1016/j.tvj1.2009.03.002

Gunun, P., Gunun, N., Cherdthong, A., Wanapat, M., Polyorach, S., Sirilaophaisan, S., ... Kang, S. (2017). In vitro rumen fermentation and methane production as affected by rambutan peel powder. Journal of Applied Animal Research, 46(1), 626-631. https://doi.org/10.1080/09712119.2017.1371608

Gxasheka, M., Louis, T., Ning, T., \& Lyu, Q. Z. (2015). An overview of tannins rich plants as alternative supplementation on ruminant animals: A Review. International Journal of Agricultural Research and Review, 3(6), 343-349.

Hagerman, A. E., \& Butler, L. G. (1981). The Specificity of Proanthocyanidin-Protein Interactions. Journal of Biological Chemistry, 256(9), 4494-4497.

Heckendorn, F., Haring, D. A., Maurer, V., Senn, M., \& Hertzberg, H. (2007). Individual administration of three tanniferous forage plants to lambs artificially infected with Haemonchus contortus and Cooperia curticei. Veterinary Parasitology, 146(1-2), 123-134. https://doi.org/10.1016/j.vetpar.2007.01.009

Hounzangbe-Adote, M. S., Paolini, V., Fouraste, I., Moutairou, K., \& Hoste, H. (2005). In vitro effects of four tropical plants on three life-cycle stages of the parasitic nematode, Haemonchus contortus. Research in Veterinary Science, 78(2), 155-160. https://doi.org/10.1016/j.rvsc.2004.05.009

Iqbal, Z., Sarwar, M., Jabbar, A., Ahmed, S., Nisa, M., Sajid, M. S., ... Yaseen, M. (2007). Direct and indirect anthelmintic effects of condensed tannins in sheep. Veterinary Parasitology, 144(1-2), 125-131. https://doi.org/10.1016/j.vetpar.2006.09.035

Jamroz, D., Wiliczkiewicz, A., Skorupińska, J., Orda, J., Kuryszko, J., \& Tschirch, H. (2009). Effect of sweet chestnut tannin (SCT) on the performance, microbial status of intestine and histological characteristics of intestine wall in chickens. British Poultry Science, 50(6), 687-699. https://doi.org/10.1080/00071660903 191059

Jonker, A., \& Yu, P. (2017). The Occurrence Biosynthesis, and Molecular Structure of Proanthocyanidins and Their Effects on Legume Forage Protein Precipitation, Digestion and Absorption in the Ruminant Digestive Tract. International Journal of Molecular Sciences, 18(1105), 2-23. https://doi.org/10.3390/ijms18051105

Jouany, J., \& Morgavi, D. P. (2017). Use of "natural" products as alternatives to antibiotic feed additives in ruminant production. Animal, 1(10), 1443-1466. https://doi.org/10.1017/S1751731107000742

Karamać, M. (2009). Chelation of $\mathrm{Cu}(\mathrm{II}), \mathrm{Zn}(\mathrm{II})$, and Fe(II) by tannin constituents of selected edible nuts. International Journal of Molecular Sciences, 10(12), 5485-5497. https://doi.org/10.3390/ijms 10125485

Krueger, W. K., Gutierrez-Bañuelos, H., Carstens, G. E., Min, B. R., Pinchak, W. E., Gomez, R. R., ... Forbes, T. D. A. (2010). Effects of dietary tannin source on performance, feed efficiency, ruminal fermentation, and carcass and non-carcass traits in steers fed a high-grain diet. Animal Feed Science and Technology, 159(1-2), 1-9. https://doi.org/10.1016/j.anifeedsci.2010.05.003

Krueger, W., Gutierrez-BaNuelos, H., Carstens, G. E., Min, B. R., Pinchak, W. E., Gomez, R. R., ... Forbes, T. D. A. (2010). Effects of dietary tannin source on performance, feed efficiency, ruminal fermentation, and carcass and non-carcass traits in steers fed a high-grain diet. Animal Feed Science and Technology, 159, 1-9. https://doi.org/10.1016/j.anifeedsci.2010.05.003

Kyarisiima, C., Okot, W. M., \& Svihus, B. (2004). Use of wood ash in the treatment of high tannin sorghum for poultry feeding. South African Journal of Animal Science, 34(2). https://doi.org/10.4314/sajas.v34i2.3814

Lee, S. H., Shinde, P. L., Choi, J. Y., Kwon, I. K., Lee, J. K., Pak, S. I., ... Chae, B. J. (2010). Effects of tannic acid supplementation on growth performance, blood hematology, iron status and faecal microflora in weanling pigs. Livestock Science, 131(2-3), 281-286. https://doi.org/10.1016/j.livsci.2010.04.013

Liu, H. W., Dong, X. F., Tong, J. M., \& Zhang, Q. (2011). A comparative study of growth performance and antioxidant status of rabbits when fed with or without chestnut tannins under high ambient temperature. Animal Feed Science and Technology, 164(1-2), 89-95. https://doi.org/10.1016/j.anifeedsci.2010.09.020

Liu, H. W., Zhou, D. W., \& Li, K. (2013). Effects of chestnut tannins on performance and antioxidative status of transition dairy cows. Journal of Dairy Science, 96(9), 5901-5907. https://doi.org/10.3168/jds.2013-6904

Liu, H., Zhou, D., Tong, J., \& Vaddella, V. (2012). Influence of chestnut tannins on welfare, carcass characteristics, meat quality, and lipid oxidation in rabbits under high ambient temperature. Meat Science, 
90(1), 164-169. https://doi.org/10.1016/j.meatsci.2011.06.019

Makkar, H. P. S. (2003). Effects and fate of tannins in ruminant animals, adaptation to tannins, and strategies to overcome detrimental effects of feeding tannin-rich feeds. Small Ruminant Research, 49(3), 241-256. https://doi.org/10.1016/S0921-4488(03)00142-1

Marles, M. A. S., Ray, H., \& Gruber, M. Y. (2003). New perspectives on proanthocyanidin biochemistry and molecular regulation. Phytochemistry, 64(2), 367-383. https://doi.org/10.1016/S0031-9422(03)00377-7

Martínez-Ortíz-de-Montellano, C., Vargas-Magaña, J. J., Canul-Ku, H. L., Miranda-Soberanis, R., Capetillo-Leal, C., Sandoval-Castro, C. A., \& Torres-Acosta, J. F. J. (2010). Effect of a tropical tannin-rich plant Lysiloma latisiliquum on adult populations of Haemonchus contortus in sheep. Veterinary Parasitology, 172(3-4), 283-290. https://doi.org/10.1016/j.vetpar.2010.04.040

Medugu, C. I., Saleh, B., Igwebuike, J. U., \& Ndirmbita, R. L. (2012). Strategies to Improve the Utilization of Tannin-Rich Feed Materials by Poultry. International Journal of Poultry Science, 11(6), 417-423. https://doi.org/10.3923/ijps.2012.417.423

Mejia-Hernandez, P., Salem, A. Z. M., Elghandour, M. M. M. Y., Cipriano-Salazar, M., Cruz-Lagunas, B., \& Camacho, L. M. (2014). Anthelmintic effects of Salix babylonica L. and Leucaena leucocephala Lam. extracts in growing lambs. Tropical Animal Health and Production, 46(1), 173-178. https://doi.org/10.1007/ s11250-013-0471-7

Min, B. R., Barry, T. N., Attwood, G. T., \& McNabb, W. C. (2003). The effect of condensed tannins on the nutrition and health of ruminants fed fresh temperate forages: A review. Animal Feed Science and Technology, 106(1), 3-19. https://doi.org/10.1016/S0377-8401(03)00041-5

Min, B. R., Pinchak, W. E., Anderson, R. C., Fulford, J. D., \& Puchala, R. (2006). Effects of condensed tannins supplementation level on weight gain and in vitro and in vivo bloat precursors in steers grazing winter wheat. Journal of Animal Science, 84(9), 2546-2554. https://doi.org/10.2527/jas.2005-590

Min, B. R., Wilson, E. A., Solaiman, S., \& Miller, J. (2015). Effects of Condensed Tannin-Rich Pine Bark Diet on Experimentally Infected With Haemonchus contortus in Meat Goats. International Journal of Veterinary Health Science \& Research, 3, 49-57. https://doi.org/10.19070/2332-2748-1500013

Minieri, S., Buccioni, A., Rapaccini, S., Pezzati, A., Benvenuti, D., Serra, A., \& Mele, M. (2014). Effect of Quebracho Tannin Extract on Soybean and Linseed Oil Biohydrogenation by Solid Associated Bacteria: An in vitro Study. Italian Journal of Animal Science, 13(3267), 604-608. https://doi.org/10.4081/ijas.2014.3267

Mokni, M., Amri, M., Limam, F., \& Aouani, E. (2017). Effect of grape seed and skin supplement on milk yield and composition of dairy ewes. Tropical Animal Health and Production, 49(1), 131-137. https://doi.org/ 10.1007/s11250-016-1169-4

Molan, A. L., Waghorn, G. C., Min, B. R., \& McNabb, W. C. (2000). The effect of condensed tannins from seven herbages on Trichostrongylus colubriformis larval migration in vitro. Folia Parasitologica, 47(1), 39-44. https://doi.org/10.14411/fp.2000.007

Mueller-Harvey, I. (2006). Unravelling the conundrum of tannins in animal nutrition and health. J Sci Food Agric, 86(2010-2037), 1-28. https://doi.org/10.1002/jsfa.2577

Naumann, H., Hagerman, A., Lambert, B., Muir, J., Tedeschi, L., \& Kothmann, M. M. (2013). Molecular weight and protein-precipitating ability of condensed tannins from warm-season perennial legumes. Journal of Plant Interactions, 9(1), 212-219. https://doi.org/10.1080/17429145.2013.811547

Nguyen, T. M., Binh, D. Van, \& Ørskov, E. R. (2005). Effect of foliages containing condensed tannins and on gastrointestinal parasites. Animal Feed Science and Technology, 121(1), 77-87. https://doi.org/10.1016/ j.anifeedsci.2005.02.013

Ngwa, A., Nsahlai, I., \& Iji, P. (2002). Effect of supplementing veld hay with a dry meal or silage from pods of Acacia sieberiana with or without wheat bran on voluntary intake, digestibility, excretion of purine derivatives, nitrogen utilization, and weight gain of South African Merino sheep. Livestock Production Science, 77(2-3), 253-264. https://doi.org/10.1016/s0301-6226(02)00035-0

Pathak, A. K., Dutta, N., Pattanaik, A. K., Chaturvedi, V. B., \& Sharma, K. (2017). Effect of condensed tannins from Ficus infectoria and Psidium guajava leaf meal mixture on nutrient metabolism, methane emission and performance of lambs. Asian Australas. J. Anim. Sci., 30(12), 1702-1710. https://doi.org/10.5713/ ajas. 17.0060 
Pérez, V., Doce, R. R., García-Pariente, C., Hervás, G., Carmen Ferreras, M., Mantecón, Á. R., \& Frutos, P. (2011). Oak leaf (Quercus pyrenaica) poisoning in cattle. Research in Veterinary Science, 91(2), 269-277. https://doi.org/10.1016/j.rvsc.2010.12.015

Petek, M., \& Dikmen, S. (2006). The effects of prestorage incubation and length of storage of broiler breeder eggs on hatchability and subsequent growth performance of progeny. Czech Journal of Animal Science, 51(2), 73-77. https://doi.org/10.17221/3912-CJAS

Piluzza, G., Sulas, L., \& Bullitta, S. (2013). Tannins in forage plants and their role in animal husbandry and environmental sustainability: A review. Grass and Forage Science, 69, 32-48. https://doi.org/10.1111/ gfs. 12053

Prevolnik, M., Škrlep, M., Brus, M., Pugliese, C., Čandek-Potokar, M., \& Škorjanc, D. (2012). Supplementing pig diet with $0.2 \%$ sweet chestnut (Castanea sativa Mill.) wood extract had no effect on growth, carcass or meat quality. Acta Agriculturae Slovenica, 100(Suppl. 3), 83-88.

Priolo, A., Waghorn, G. C., Lanza, M., Biondi, L., \& Pennisi, P. (2000). Polyethylene glycol as a means for reducing the impact of condensed tannins in carob pulp: Effects on lamb growth performance and meat quality. Journal of Animal Science, 78(4), 810-816. https://doi.org/10.2527/2000.784810x

Priolo, Q., \& Vasta, V. (2007). Effects of tannin-containing diets on small ruminant meat quality. Italian Journal of Animal Science, 6, 527-530. https://doi.org/10.4081/ijas.2007.1s.527

Puchala, R., Min, B. R., Goetsch, A. L., \& Sahlu, T. (2005). The effect of a condensed tannin-containing forage on methane emission by goats. Journal of Animal Science, 83(1), 182-186. https://doi.org//2005.831182x

Rochfort, S., Parker, A. J., \& Dunshea, F. R. (2008). Plant bioactives for ruminant health and productivity. Phytochemistry, 69(2), 299-322. https://doi.org/10.1016/j.phytochem.2007.08.017

Schiavone, A., Guo, K., Tassone, S., Gasco, L., Hernandez, E., Denti, R., \& Zoccarato, I. (2008). Effects of a natural extract of chestnut wood on digestibility, performance traits, and nitrogen balance of broiler chicks. Poultry Science, 87(3), 521-527. https://doi.org/10.3382/ps.2007-00113

Shewangzaw, A. (2016). Effect of Dietary Tannin Source Feeds on Ruminal Fermentation and Production of Cattle: A Review. Journal of Animal and Feed Research, 6(2), 45-56.

Tiemann, T. T., Lascano, C. E., Wettstein, H.-R., Mayer, A. C., Kreuzer, M., \& Hess, H. D. (2008). Effect of the tropical tannin-rich shrub legumes Calliandra calothyrsus and Flemingia macrophylla on methane emission and nitrogen and energy balance in growing lambs. Animal: An International Journal of Animal Bioscience, 2(5), 790-799. https://doi.org/10.1017/S1751731108001791

Vasta, V., Yanez-Ruiz, D. R., Mele, M., Serra, A., Luciano, G., Lanza, M., ... Priolo, A. (2010). Bacterial and protozoal communities and fatty acid profile in the rumen of sheep fed a diet containing added tannins. Applied and Environmental Microbiology, 76(8), 2549-2555. https://doi.org/10.1128/AEM.02583-09

Vitti, D. M. S. S., Abdalla, A. L., Bueno, I. C. S., Filho, J. C. S., Costa, C., Bueno, M. S., ... Mueller-Harvey, I. (2005). Do all tannins have similar nutritional effects? A comparison of three Brazilian fodder legumes. Animal Feed Science and Technology, 119(3-4), 345-361. https://doi.org/10.1016/j.anifeedsci.2004.06.004

Waghorn, G. (2008). Beneficial and detrimental effects of dietary condensed tannins for sustainable sheep and goat production-Progress and challenges. Animal Feed Science and Technology, 147(1-3), 116-139. https://doi.org/10.1016/j.anifeedsci.2007.09.013

Wang, Y., Majak, W., \& McAllister, T. A. (2012). Frothy bloat in ruminants: Cause, occurrence, and mitigation strategies. Animal Feed Science and Technology, 172(1), 103-114. https://doi.org/10.1016/j.anifeedsci. 2011.12.012

Wang, Y., McAllister, T. A., \& Acharya, S. (2015). Condensed Tannins in Sainfoin: Composition, Concentration, and Effects on Nutritive and Feeding Value of Sainfoin Forage. Crop Science, 55, 13-22. https://doi.org/ 10.2135/cropsci2014.07.0489

Ying, S., Wang, Z., Wang, C., Nie, H., He, D., Jia, R., ... Wang, F. (2011). Effect of different levels of short-term feed intake on folliculogenesis and follicular fluid and plasma concentrations of lactate dehydrogenase, glucose, and hormones in Hu sheep during the luteal phase. Reproduction, 142(5), 699-710. https://doi.org/ 10.1530/REP-11-0229 


\section{Copyrights}

Copyright for this article is retained by the author(s), with first publication rights granted to the journal.

This is an open-access article distributed under the terms and conditions of the Creative Commons Attribution license (http://creativecommons.org/licenses/by/4.0/). 